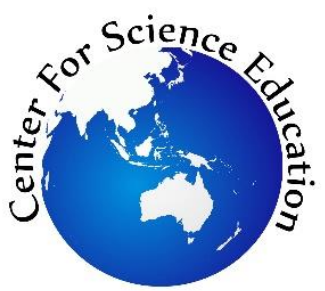

\author{
Tersedia online di EDUSAINS \\ Website: http://journal.uinjkt.ac.id/index.php/edusains
}

EDUSAINS, 13(1), 2021, 1-7

Research Artikel

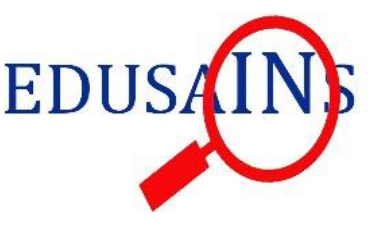

\title{
ANALISIS KETERAMPILAN PROSES SAINS DAN SIKAP ILMIAH SISWA KELAS XI IPA SMA PADA PRAKTIKUM BIOLOGI
}

\section{ANALYSIS SCIENCE PROCESS SKILLS AND SCIENTIFIC ATTITUDES OF XI GRADE STUDENTS OF SENIOR HIGH SCHOOL IN BIOLOGICAL PRACTICE}

\author{
Putri Agustina $^{1 *}$, Alanindra Saputra ${ }^{2}$, Sofyan Anif ${ }^{1}$, Anis Rayana ${ }^{1}$, Annisa Probowati ${ }^{1}$ \\ ${ }^{1}$ Program Studi Pendidikan Biologi FKIP Universitas Muhammadiyah Surakarta \\ ${ }^{2}$ Program Studi Pendidikan Biologi FKIP Universitas Sebelas Maret
}

pa182@ums.ac.id

\begin{abstract}
Practicum is one of the learning methods that cannot be separated from Biology learning. If implemented properly, the practicum can develop science process skills and students' scientific attitudes. This study aims to: (a) analyze student science process skills in Biology practicum at Surakarta State Senior High School 2; (b) analyzing the scientific attitude of students in the Biology practicum at Surakarta State Senior High School 2; and (c) analyzing the effectiveness of Biology practicum in developing science process skills and students' scientific attitudes. This research is a descriptive study conducted at SMA Negeri 2 Surakarta in March to May 2018. The population in this study were all students of class XI IPA SMA Negeri 2 Surakarta even semester 2017/2018 school year totaling 128 students while the sample was taken purposively sampling a total of 56 students. Science process skills data is obtained from the results of the observation sheet analysis while the scientific attitude data is obtained from the observation sheet and student questionnaire. Based on the results of data analysis, it was found that: (1) the science process skills class XI IPA of SMA 2 Surakarta in the Biology lab was categorized very well with the average score of KPS 82.03; and (2) the scientific attitude of the 11th grade students of SMAN 2 Surakarta is in the average category with an average score of 68.63. Thus, it can be concluded that Biology practicum can develop science process skills and students' scientific attitudes.
\end{abstract}

Keywords: practicum; Biology teaching and learning; science process skills; scientific attitude; effectiveness

\section{Abstrak}

Praktikum merupakan salah satu metode pembelajaran yang tidak dapat dipisahkan dari pembelajaran Biologi. Jika dilaksanakan dengan baik, maka praktikum dapat melatihkan keterampilan proses sains (KPS) serta mengembangkan sikap ilmiah siswa. Penelitian ini bertujuan untuk: (a) menganalisis KPS siswa pada praktikum Biologi di SMA Negeri 2 Surakarta; dan (b) menganalisis sikap ilmiah siswa pada praktikum Biologi di SMA Negeri 2 Surakarta. Penelitian ini merupakan penelitian deskriptif yang dilaksanakan di SMA Negeri 2 Surakarta pada bulan Maret sampai dengan Mei 2018. Populasi pada penelitian ini adalah seluruh siswa kelas XI IPA SMA Negeri 2 Surakarta semester genap tahun pelajaran 2017/2018 yang berjumlah 128 siswa sedangkan sampel diambil secara purposive sampling sejumlah 56 siswa. Data KPS diperoleh dari hasil analisis lembar observasi sedangkan data sikap ilmiah diperoleh dari lembar observasi dan angket siswa. Berdasarkan hasil analisis data diperoleh hasil bahwa: (1) KPS kelas XI IPA SMAN 2 Surakarta pada praktikum Biologi dikategorikan sangat baik dengan perolehan rata-rata skor KPS 82.03; serta (2) sikap ilmiah siswa kelas XI IPA SMAN 2 Surakarta masuk dalam kategori cukup baik dengan rata-rata skor 68.63. Dengan demikian, dapat disimpulkan bahwa praktikum Biologi dapat mengembangkan KPS dan sikap ilmiah siswa.

Kata Kunci: praktikum; pembelajaran Biologi; keterampilan proses sains; sikap ilmiah

Permalink/DOI: http:// doi.org/10.15408/es.v13i1.11015 


\section{PENDAHULUAN}

Biologi merupakan bagian dari sains (ilmu pengetahuan alam) yang mempelajari tentang makhluk hidup. Sebagai bagian dari sains, Biologi tersusun atas banyak teori-teori tentang makhluk hidup, kehidupan, dan lingkungan yang melingkupinya (Dewi, Sunariyati, \& Neneng, 2016). Sebagai bagian dari sains, karakter Biologi mengacu pada karakteristik sains. Karakteristik sains yaitu merupakan hasil dari proses penemuan, tidak hanya berupa kumpulan pengetahuan dalam bentuk fakta, prinsip, teori atau hukum. Sains diperoleh melalui interaksi antara permasalahan (pertanyaan) yang terjadi secara berkelanjutan dengan lingkungan fisik di sekitar makhluk hidup (Rustaman, 2011).

Karakter Biologi seperti yang dipaparkan di atas berimplikasi pada tuntutan pembelajaran Biologi. Pembelajaran Biologi harus dilaksanakan sesuai dengan hakekat Biologi sebagai bagian dari sains. Pembelajaran Biologi menurut (Sudarisman, 2018) harus diarahkan untuk menciptakan suasana aktif, kritis, analisis, dan kreatif dalam pemecahan masalah melalui pengembangan kemampuan berpikir. Hal ini selaras dengan yang tertuang pada Peraturan Menteri Pendidikan dan Kebudayaan (Permendikbud) Nomor 22 Tahun 2016 tentang Standar Proses Pendidikan Dasar dan Menengah bahwa proses pembelajaran, termasuk Biologi, diselenggarakan secara interaktif, inspiratif, menyenangkan, menantang, memotivasi peserta didik untuk berpartisipasi aktif, serta memberikan ruang yang cukup bagi prakarsa, kreativitas, dan kemandirian sesuai dengan bakat, minat, dan perkembangan fisik serta psikologis peserta didik.

Salah satu aspek Biologi sebagai sains adalah Biologi sebagai proses. Biologi sebagai proses merupakan cara untuk memecahkan masalah melalui langkah-langkah sistematis yang dikenal dengan metode ilmiah. Biologi menyediakan berbagai pengalaman belajar untuk memahami konsep dan proses sains. Karakter tersebut yang memunculkan konsep keterampilan proses sains/ KPS (Surachman, 2014). Mata pelajaran Biologi berkaitan dengan mencari tahu dan memahami alam secara sistematis sehingga bukan hanya mengumpulkan pengetahuan tetapi lebih kepada proses penemuan. Proses penemuan yang dilakukan melalui pembelajaran Biologi mendorong munculnya KPS.

KPS merupakan serangkaian keterampilan yang melibatkan keterampilan intelektual, manual, dan sosial. KPS melibatkan serangkaian kegiatan manual (hands on) seperti: mengamati, mengklasifikasi, mengukur, menghitung, memprediksi, mengkomunikasikan, bertanya, membuat kesimpulan, mengontrol variabel, merumuskan masalah, membuat hipotesis, serta merancang percobaan (Sudarisman, 2018). Jika merujuk pada karakter dan hakekat Biologi sebagai sains, maka pengembangan KPS menjadi sesuatu yang wajib dipenuhi pada pembelajaran Biologi. Namun, hal ini masih belum sepenuhnya dapat terwujud dalam pembelajaran Biologi di sekolah. KPS masih menjadi masalah tersendiri bagi proses belajar mengajar di sekolah karena capaiannya yang masih rendah. Rendahnya KPS lebih banyak disebabkan oleh metode pembelajaran yang digunakan guru kurang dapat mengembangkan KPS (Nirwana, Nyeneng, \& Maharta, 2014; Syafriyansyah, Eko Suyanto, \& I Dewa Putu Nyeneng, 2013).

KPS dapat dilatihkan melalui penggunaan berbagai macam model dan metode pembelajaran. Salah satu metode pembelajaran yang dapat melatihkan KPS adalah praktikum. Kegiatan praktikum dapat membuat konsep yang abstrak menjadi lebih mudah dipahami. Oleh karena materi Biologi merupakan materi yang mempelajari makhluk hidup yang didalamnya tersusun atas banyak teori tentang kehidupan, maka untuk membuktikan kebenaran teori tersebut perlu dilaksanakan praktikum. Praktikum menurut (Falahudin, Fauzi, \& Purnamasari, 2016) menjadi jembatan penghubung antara pengembangan pengetahuan (kognitif), afektif (sikap), dan psikomotorik (keterampilan). Praktikum menjadi sarana untuk memberikan pengalaman langsung kepada siswa sehingga materi dan kegiatan pembelajaran menjadi lebih terpadu (Dewi et al., 2016). Hal ini didukung hasil penelitian (Arisman \& Permanasari, 2015) yang menyatakan pembelajaran dengan model pembelajaran kooperatif tipe STAD dengan metode praktikum 
dapat meningkatkan literasi sains siswa. Pembelajaran sains yang dilaksanakan secara terpadu akan membuat siswa memperoleh pengalaman secara langsung karena pembelajaran ini bertujuan untuk mengembangkan kemampuan aplikatif, pengembangan kemampuan berpikir, kemampuan belajar dan sikap ilmiah. Sehingga selain dapat mengembangkan KPS, maka praktikum juga akan melatihkan berbagai sikap ilmiah.

Sikap ilmiah merupakan disposisi berpikir yang menjadi trend penelitian yang terintegrasi dalam keterampilan berpikir tingkat tinggi seperti berpikir kritis, kreatif, metakognisi, problem solving dan decision making, serta sangat menentukan kualitas individu siswa. Beberapa aspek sikap ilmiah seperti keingintahuan, kepedulian, kewaspadaan, kepercayaan diri, berpikir terbuka, fleksibilitas, menghormati pendapat orang lain, berpikir adil, jujur, hati-hati, dan lain sebagainya yang menjadi disposisidisposisi berpikir yang mencirikan kualitas berpikir seseorang (Hunaepi, 2016). Sikap ilmiah dapat dilatihkan melalui berbagai macam metode pembelajaran salah satunya adalah praktikum (Ulfa, 2016; Zulyetti, 2017; Suryaningsih, 2017).

SMA Negeri 2 Surakarta merupakan salah satu sekolah negeri di kota Surakarta. Berdasarkan hasil observasi laboratorium, SMA Negeri 2 Surakarta merupakan SMA Negeri di Surakarta yang mempunyai fasilitas yang lengkap, salah satunya yaitu memiliki laboratorium yang lengkap yaitu laboratorium kimia, fisika, dan biologi. Hasil penelitian (Lathifah, 2018) menunjukkan bahwa kualitas laboratorium Biologi di SMA Negeri 2 Surakarta tahun pelajaran 2017/2018 masuk dalam kategori sangat baik dengan rata-rata persentase capaian $81.3 \%$ dan pengelolaan laboratorium masuk dalam kategori sangat baik dengan rata-rata persentase capaian $87.5 \%$. Hasil wawancara dengan salah satu guru matapelajaran Biologi di SMA Negeri 2 Surakarta menunjukkan bahwa secara umum, pembelajaran Biologi lebih dilaksanakan secara teoritis dengan metode ceramah. Di SMA Negeri 2 Surakarta sangat jarang dilaksanakan praktikum karena keterbatasan waktu pembelajaran dan kurangnya guru/laboran. Pada penelitian ini, fokus pada kegiatan praktikum yang dilaksanakan di kelas XI IPA SMA Negeri 2 Surakarta.

Tujuan penelitian ini adalah untuk menganalisis pelaksanaan praktikum Biologi kelas XI IPA SMA Negeri 2 Surakarta ditinjau dari KPS dan sikap ilmiah siswa. Pemilihan materi sistem pencernaan dan pernafasan didasarkan pada analisis kompetensi dasar yang dilakukan bersama guru matapelajaran dimana kedua materi tersebut yang dipraktikumkan di semester berjalan.

\section{METODE}

Penelitian ini merupakan penelitian deskriptif yang bertujuan mendeskripsikan KPS dan sikap ilmiah siswa kelas XI IPA SMA Negeri 2 Surakarta pada praktikum Biologi. Penelitian dilaksanakan di SMA Negeri 2 Surakarta pada bulan Februari sampai dengan Agustus 2018. Data yang akan dideskripsikan pada penelitian ini adalah KPS dan sikap ilmiah siswa kelas XI IPA SMA Negeri 2 Surakarta pada praktikum Biologi. Populasi pada penelitian ini adalah seluruh siswa kelas XI IPA SMA Negeri 2 Surakarta Semester Genap Tahun Pelajaran 2017/2018 yang berjumlah 128 siswa sedangkan sampel menggunakan perhitungan rumus Taro Yamane sebesar 56 siswa dari kelas XI IPA 1 dan XI IPA 2 yang dipilih secara purposive sampling. Data, sumber data, dan teknik pengumpulan data pada penelitian ini disajikan pada Tabel 1. Data KPS dan sikap ilmiah yang diperoleh berdasarkan hasil observasi, angket, dokumentasi, dan wawancara kemudian dianalisis secara deskriptif dengan teknik persentase. Observasi dilaksanakan per-siswa dengan melibatkan beberapa observer. Data hasil observasi KPS siswa dianalisis menggunakan rumus:

$$
\text { KPS }=\frac{\text { Capaian Skor KPS }}{\text { Skor KPS maksimal }} \times 100 \%
$$

yang kemudian diinterpretasikan menjadi lima kategori menurut Arikunto (2007) seperti ditunjukkan pada Tabel 2 . 
Tabel 2. Kategori KPS

\begin{tabular}{ll}
\hline \multicolumn{1}{c}{ Persentase } & \multicolumn{1}{c}{ Kategori KPS } \\
\hline $81-100 \%$ & Sangat Baik \\
$61-80 \%$ & Baik \\
$41-60 \%$ & Cukup Baik \\
$21-40 \%$ & Kurang Baik \\
$0-20 \%$ & Sangat Kurang Baik
\end{tabular}

Data sikap ilmiah diperoleh berdasarkan hasil observasi dan hasil angket. Observasi dilaksanakan per siswa dengan melibatkan beberapa observer. Sedangkan angket dikembangkan dengan menggunakan skala Likert. Hasil observasi dan angket kemudian dibandingkan sebagai bentuk triangulasi metode.

Tabel 3. Data, Sumber Data, dan Teknik Pengumpulan Data

\begin{tabular}{|c|c|c|c|}
\hline Aspek & Sub Aspek & $\begin{array}{c}\text { Sumber } \\
\text { Data }\end{array}$ & $\begin{array}{c}\text { Teknik } \\
\text { Pengumpulan } \\
\text { Data }\end{array}$ \\
\hline $\begin{array}{l}\text { Keterampila } \\
\text { n Proses } \\
\text { Sains (KPS) } \\
\text { (Rustaman, } \\
\text { 2005 dan } \\
\text { Dimyati, } \\
\text { 2013) }\end{array}$ & $\begin{array}{l}\text { - Keterampilan } \\
\text { melakukan } \\
\text { observasi } \\
\text { - Keterampilan } \\
\text { menggunakan } \\
\text { alat dan bahan } \\
\text { - Keterampilan } \\
\text { memprediksi } \\
\text { - Keterampilan } \\
\text { melakukan } \\
\text { pengukuran } \\
\text { - Keterampilan } \\
\text { menginterpreta } \\
\text { sikan data } \\
\text { - Keterampilan } \\
\text { berkomunikasi } \\
\text { secara tertulis }\end{array}$ & $\begin{array}{c}\text { Siswa } \\
\text { kelas XI } \\
\text { IPA } \\
\text { SMA } \\
\text { Negeri } 2 \\
\text { Surakart } \\
\text { a }\end{array}$ & $\begin{array}{ll}- & \text { Observasi } \\
\text { - } & \text { Dokumenta } \\
& \text { si }\end{array}$ \\
\hline $\begin{array}{c}\text { Sikap } \\
\text { Ilmiah } \\
\text { (Anggraini, } \\
\text { 2017) }\end{array}$ & $\begin{array}{l}\text { - Rasa ingin tahu } \\
\text { - Respek } \\
\text { terhadap data } \\
\text { dan fakta } \\
\text { - Kritis terhadap } \\
\text { informasi yang } \\
\text { diterima } \\
\text { - Kreatif } \\
\text { - Kerjasama }\end{array}$ & $\begin{array}{c}\text { Siswa } \\
\text { kelas XI } \\
\text { IPA } \\
\text { SMA } \\
\text { Negeri } 2 \\
\text { Surakart } \\
\text { a }\end{array}$ & $\begin{array}{ll}\text { - } & \text { Observasi } \\
\text { - } & \text { Angket } \\
\text { - } & \text { Dokumenta } \\
& \text { si }\end{array}$ \\
\hline
\end{tabular}

\section{HASIL DAN PEMBAHASAN}

Biologi merupakan bagian dari IPA yang di dalam pembelajarannya tidak hanya menekankan pada penguasaan kumpulan pengetahuan yang berupa fakta, konsep, atau prinsip saja tetapi juga merupakan suatu proses penemuan. Proses belajar mengajar pada matapelajaran Biologi merupakan keterkaitan antara kegiatan di dalam kelas untuk mempelajari teori dan praktikum di laboratorium untuk menguji teori. Pelaksanaan praktikum di sekolah dipengaruhi oleh sarana dan prasarana, alokasi waktu, dan lain sebagainya. Pembelajaran Biologi di kelas dan praktikum di laboratorium harus berjalan secara seimbang agar dapat memaksimalkan potensi pengembangan ranah kognitif, afektif, dan psikomotor secara berimbang (Falahudin et al., 2016). Praktikum menjadi salah satu wahana untuk memberikan pengalaman langsung kepada siswa dalam mengembangkan kompetensi menjelajahi dan memahami alam secara sistematis. Melalui praktikum siswa memiliki peluang mengembangkan dan menerapkan keterampilan proses sains dan sikap ilmiah dalam rangka memperoleh pengetahuannya (Subiantoro, 2014). Penelitian ini bertujuan untuk mendeskripsikan efektifitas pelaksanaan praktikum Biologi kelas XI SMA Negeri 2 Surakarta tahun pelajaran 2017/2018 jika ditinjau dari capaian KPS dan sikap ilmiah siswa. Hasil analisis terhadap data KPS dan sikap ilmiah siswa secara umum akan diuraikan sebagai berikut.

\section{Deskripsi Keterampilan Proses Sains (KPS) Siswa Kelas XI IPA SMA Negeri 2 Surakarta pada Praktikum Biologi}

KPS menurut (Astari, 2018) merupakan keterampilan yang sangat penting dalam pembelajaran sains. KPS dalam pembelajaran sains sering diidentikkan dengan salah satu pendekatan pembelajaran yaitu pendekatan keterampilan proses. Pendekatan keterampilan proses merupakan pendekatan pembelajaran yang menekankan integrasi antara berbagai keterampilan yang kompleks seperti mental, fisik, dan sosial yang diharapkan dapat dijadikan sebagai penggerak bagi kemampuan yang lebih tinggi.

Data hasil observasi KPS siswa kelas XI IPA SMA Negeri 2 Surakarta pada praktikum Biologi diperoleh dari dua kali observasi yaitu pada materi sistem Pencernaan dan sistem Respirasi. Pemilihan materi yang diobservasi berdasarkan rencana pelaksanaan pembelajaran (RPP) yang disusun guru dan hasil wawancara yang menyatakan bahwa hanya dua materi tersebut yang diprak-tikumkan pada semester genap tahun pelajaran 2017/2018.

Tabel 4. Hasil Observasi KPS Siswa Kelas XI IPA SMA Negeri 2 Surakarta pada Praktikum Biologi

\begin{tabular}{lcl}
\hline \multicolumn{1}{c}{ Materi } & $\begin{array}{c}\text { Rata-Rata Skor } \\
\text { KPS }\end{array}$ & Kategori \\
\hline $\begin{array}{l}\text { Sistem } \\
\text { Pencernaan } \\
\text { Sistem } \\
\text { Respirasi }\end{array}$ & 80,53 & Baik \\
\hline Rata-Rata & 83,53 & Sangat Baik \\
\hline
\end{tabular}


Tabel 5. Hasil Observasi KPS Siswa Kelas XI IPA SMA Negeri 2 Surakarta pada Praktikum Biologi Semester Genap Tahun Pelajaran 2017/2018 jika Ditinjau per Aspek

\begin{tabular}{lllll}
\hline \multirow{2}{*}{ Aspek } & Materi & \multicolumn{2}{l}{ Rata-Rata } & Kategori \\
\cline { 2 - 3 } & Sistem & Sistem & & \\
\cline { 1 - 2 } Keterampilan melakukan observasi & 92,25 & 96,25 & 94,25 & Sangat Baik \\
Keterampilan menggunakan alat dan bahan & 75,25 & 73,75 & 74,25 & Baik \\
Keterampilan memprediksi & 71,25 & 69,50 & 70,38 & Baik \\
Keterampilan melakukan pengukuran & 50,00 & 75,00 & 62,50 & Baik \\
Keterampilan menginterpretasikan data & 90,75 & 92,75 & 91,75 & Sangat Baik \\
Keterampilan mengimplementasikan prosedur & 98,75 & 99,00 & 98,87 & Sangat Baik \\
Keterampilan berkomunikasi & 85,50 & 78,50 & 82,00 & Sangat Baik \\
\hline Rata-Rata & 80,53 & 83,53 & 82,03 & Sangat Baik \\
\hline
\end{tabular}

Berdasarkan Tabel 4, diketahui bahwa secara umum, rata-rata capaian skor KPS siswa kelas XI IPA SMA Negeri 2 Surakarta pada semester genap tahun pelajaran 2017/2018 masuk dalam kategori sangat baik dengan rata-rata sebesar 82,03 . Jika dilihat per materi yang dipraktikumkan, maka dapat diketahui bahwa pada materi sistem pencernaan, rata-rata skor KPS adalah 80,53 sedangkan pada materi sistem respirasi, rata-rata skor KPS mencapai 82,03 (Tabel 4). Hal ini menunjukkan bahwa kegiatan praktikum yang telah dilaksanakan guru dapat mengembangkan KPS siswa. Aspek KPS yang diamati meliputi keterampilan melakukan observasi, menggunakan alat dan bahan, memprediksi, melakukan pengukuran, menginterpretasikan data, mengimplementasikan prosedur, serta keterampilan berkomunikasi.

Tabel 5 menunjukkan bahwa rata-rata skor KPS siswa jika ditinjau per aspek berbeda pada kedua materi yang dipraktikumkan. Pada kedua materi yang dipraktikumkan, rata-rata skor aspek tertinggi pada aspek keterampilan mengimplementasikan prosedur sedangkan rata-rata skor aspek terendah pada keterampilan memprediksi.

Hasil penelitian Bahtiar (2017) menunjukkan bahwa penggunaan model praktikum fisika berbasis guided inquiry berpengaruh terhadap peningkatan KPS. Pembelajaran ini mampu menarik minat dan motivasi mahasiswa karena masalah yang diungkapkan dikaitkan dengan pengalaman mahasiswa dalam kehidupan sehari-hari. Selain itu, penelitian (Lepiyanto, 2017) menujukkan bahwa ada beberapa aspek KPS yang dapat berkembang melalui pembelajaran berbasis praktikum yaitu mengamati, mengkomunikasi data, dan mengajukan pertanyaan.
Aspek-aspek KPS yang teramati tentu bergantung pada karakteristik materi yang dipraktikumkan dan proses pembelajaran dengan metode praktikum pada materi tersebut. Hasil penelitian Syafriyansyah et al. (2013) menunjukkan bahwa masing-masing aspek KPS memiliki relevansi tersendiri dalam menentukan hasil belajar siswa. Melalui pelaksanaan metode praktikum, maka siswa dapat dilatih memunculkan permasalahan, menganalisis fenomena, mengajukan hipotesis, merencanakan eksperimen, melaksanakan eksperimen, mengumpulkan data, sampai menginterpretasikan data. Keterlibatan aktif siswa dalam beberapa langkah tersebut diharapkan mampu meningkatkan retensi materi pembelajaran yang telah dipelajari sehingga dapat berdampak positif terhadap hasil belajar siswa. Hal ini didukung hasil penelitian Nirwana et al. (2014) bahwa KPS berpengaruh terhadap hasil belajar siswa dengan kontribusi 57,5\%.

Jika dilihat secara skor keseluruhan pada tiap aspek, maka aspek dengan KPS dengan skor capaian tertinggi adalah keterampilan mengimplementasikan prosedur yaitu $98,87 \%$ sedangkan capaian terendah adalah pada aspek keterampilan melakukan pengukuran yaitu $62,50 \%$. Keterampilan melakukan pengukuran merupakan salah satu bagian dari keterampilan mengamati. Dimyati (2009) dalam Khairunnisa dkk (2019) berpendapat bahwa keterampilan mengamati muncul sebagai tanggapan atas berbagai objek dan peristiwa alam dengan menggunakan panca indera. Mengamati menjadi salah satu keterampilan yang paling dasar sebagai dasar berkembangnya aspek KPS yang lain. 


\section{Deskripsi Sikap Ilmiah Siswa Kelas XI IPA SMA Negeri 2 Surakarta pada Praktikum Biologi}

Sikap ilmiah menurut Muslich (2008) dalam Ulfa (2016) merupakan sikap yang ada pada diri ilmuwan dalam menghadapi permasalahanpermasalahan ilmiah. Sikap ilmiah dapat berupa sikap seseorang terhadap sains atau sikap yang akan diperoleh seseorang setelah mempelajari sains. Sikap ilmiah merupakan bagian yang tidak terpisahkan dari pembelajaran IPA termasuk Biologi. Biologi berisi materi yang berupa fakta, konsep, teori, hukum dan prinsip tentang alam beserta fenomena yang terjadi di dalamnya. Produk-produk tersebut tidak diperoleh begitu saja namun melalui serangkaian proses eksperimen dan penyelidikan. Melalui proses tersebut, maka dapat dikembangkan sikap ilmiah.

Tabel 6. Hasil Observasi dan Angket Sikap Ilmiah Siswa Kelas XI IPA SMA Negeri 2 Surakarta pada Praktikum Biologi Semester Genap Tahun Pelajaran 2017/2018

\begin{tabular}{|c|c|c|c|c|}
\hline \multirow{2}{*}{ Aspek } & \multicolumn{2}{|l|}{ Skor } & \multirow{2}{*}{$\begin{array}{l}\text { Rata- } \\
\text { Rata }\end{array}$} & \multirow[t]{2}{*}{ Kategori } \\
\hline & Observasi & Angket & & \\
\hline $\begin{array}{l}\text { Rasa ingin } \\
\text { tahu }\end{array}$ & 78,5 & 71 & 74,75 & Cukup Baik \\
\hline $\begin{array}{l}\text { Respek } \\
\text { terhadap } \\
\text { data dan } \\
\text { fakta }\end{array}$ & 70,4 & 67 & 68,67 & Cukup Baik \\
\hline $\begin{array}{l}\text { Kritis } \\
\text { terhadap } \\
\text { informasi } \\
\text { yang } \\
\text { diterima }\end{array}$ & 62,7 & 70 & 66,34 & Cukup Baik \\
\hline Kreatif & 65,9 & 58 & 61,98 & Cukup Baik \\
\hline Kerjasama & 78,8 & 64 & 71,41 & Cukup Baik \\
\hline Rata-Rata & 71,26 & 66 & 68,63 & Cukup Baik \\
\hline
\end{tabular}

Sikap ilmiah dapat dikembangkan melalui berbagai macam metode pembelajaran salah satunya adalah praktikum. Pada penelitian ini, data sikap ilmiah siswa kelas XI IPA SMA Negeri 2 Surakarta pada Praktikum Biologi semester genap tahun pelajaran 2017/2018 diperoleh dari hasil observasi pada saat berlangsung praktikum dengan hasil angket yang diisi siswa (Tabel 5). Hasil analisis sikap ilmiah siswa disajikan secara lengkap pada Tabel 6.
Tabel 5 menunjukkan bahwa rata-rata sikap ilmiah siswa kelas XI IPA SMA Negeri 2 Surakarta pada praktikum Biologi semester genap 2017/2018 masuk dalam kategori cukup baik dengan capaian skor sebesar 68.63. Jika dilihat per aspek, maka aspek rasa ingin tahu memiliki rata-rata tertinggi yaitu 74.75 sedangkan yang terendah pada aspek sikap kreatif yaitu sebesar 61.98. Hal ini didukung hasil penelitian Ulva, Ibrohim, \& Sutopo (2017) dan Ulfa (2016) bahwa pembelajaran berbasis praktikum dapat digunakan sebagai sarana untuk mengembangkan sikap ilmiah siswa.

\section{PENUTUP}

Berdasarkan hasil analisis data, rata-rata capaian skor KPS siswa kelas XI IPA SMA Negeri 2 Surakarta pada semester genap tahun pelajaran 2017/2018 masuk dalam kategori sangat baik dengan rata-rata sebesar 82.03. Sedangkan rata-rata capaian sikap ilmiah sebesar 68.63 atau masuk dalam kategori cukup baik. Hal ini menunjukkan bahwa kegiatan praktikum yang telah dilaksanakan guru dapat mengembangkan KPS siswa. Saran yang dapat diberikan diantaranya adalah perlu dilakukan penelitian lebih lanjut tentang bagaimana implikasi KPS dan sikap ilmiah siswa pada pembelajaran praktikum terhadap hasil belajar siswa.

\section{UCAPAN TERIMA KASIH}

Ucapan terimakasih disampaikan kepada kepala SMA Negeri 2 Surakarta yang telah memberikan ijin dilaksanakannya penelitian ini. Kepada guru mata pelajaran Biologi kelas XI IPA SMA Negeri 2 Surakarta serta siswa kelas XI IPA 1 dan XI IPA 2 sebagai subjek penelitian.

\section{DAFTAR PUSTAKA}

Arikunto, S. (2007). Manajemen Penelitian. Jakarta: Rineka Cipta

Arisman, A., \& Permanasari, A. (2015). Penerapan Pembelajaran Kooperatif Tipe STAD dengan Metode Praktikum dan Demonstrasi Multimedia Interaktif (MMI) dalam Pembelajaran IPA Terpadu untuk Meningkatkan Literasi Sains Siswa. Edusains, 7(2), 179-184.

Astari, W. (2018). Pengembangan Keterampilan Proses Sains Melalui Metode Penemuan. Jurnal 
Pendidikan Biologi, 6(2), 317-322. http://doi.org/10.24114/jpb.v6i2.6547

Bahtiar. (2017). Pengaruh Model Praktikum Fisika Berbasis Guided Inkuiri untuk Meningkatkan Keterampilan Proses Sains Mahasiswa Pendidikan Fisika UIN Mataram. In Prosiding Seminar Nasional Pendidik dan Pengembang Pendidikan Indonesia (pp. 82-88). Mataram: Asosiasi Pendidik dan Pengembang Pendidikan Indonesia (APPPI) Wilayah Provinsi Nusa Tenggara Barat Kerjasama Lembaga Penelitian dan Pendidikan (LPP) Mandala. http://doi.org/S0962-8924(12)00067-0 [pii] \n10.1016/j.tcb.2012.04.004

Dewi, I. S., Sunariyati, S., \& Neneng, L. (2016). Analisis Kendala Pelaksanaan Praktikum Biologi di SMA Negeri se-Kota Palangka Raya. EduSains, 2(1), 13-26.

Falahudin, I., Fauzi, M., \& Purnamasari, W. (2016). PEMBELAJARAN BERBASIS PROYEK DALAM PRAKTIKUM BIOLOGI TERHADAP KETERAMPILAN PROSES SAINS SISWA SMP MUHAMMADIYAH 6 PALEMBANG

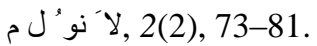

Hunaepi. (2016). Kajian Literatur tentang Pentingnya Sikap Ilmiah. In Prosiding Seminar Nasional Pusat Kajian Pendidikan Sains dan Matematika Tahun 2016 (pp. 548-550). Mataram: IKIP Mataram.

Khairunnisa, Ita, Istiqamah. (2019). Keterampilan Proses Sains (KPS) Mahasiswa Tadris Biologi pada Matakuliah Biologi Umum. BIO-INOVED: Jurnal Biologi-Inovasi Pendidikan. 1(2): 58-65.

Lathifah, H. (2018). Kualitas Pengelolaan Laboratorium Biologi di SMA Negeri 2 Surakarta Tahun Pelajaran 2017/2018. Universitas Muhammadiyah Surakarta.

Lepiyanto, A. (2017). Analisis Keterampilan Proses Sains Pada Pembelajaran Berbasis Praktikum. BIOEDUKASI (Jurnal Pendidikan Biologi), 5(2), 156. http://doi.org/10.24127/bioedukasi.v5i2.795

Nirwana, F. B., Nyeneng, I. D. P., \& Maharta, N. (2014). Pengaruh Keterampilan Proses Sainsterhadap Hasil Belajar Pada Model Latihan Inkuiri. Jurnal Pembelajaran Fisika, 2(3), 31-42. http://doi.org/10.11225/jcss.22.426
Rustaman, N. Y. (2011). Pendidikan dan Penelitian Sains dalam Mengembangkan Keterampilan Berpikir Tingkat Tinggi untuk Pembangunan Karakter. In Seminar Nasional XI Pendidikan Biologi (pp. 15-34). Surakarta: Program Studi Pendidikan Biologi FKIP Universitas Sebelas Maret.

Subiantoro, A. W. (2014). Pentingnya Praktikum dalam Pembelajaran IPA. Yogkayarta.

Sudarisman, S. (2018). Memahami Hakikat Dan Karakteristik Pembelajaran Biologi Dalam Upaya Menjawab Tantangan Abad 21 Serta Optimalisasi Implementasi Kurikulum 2013. Florea: Jurnal Biologi Dan Pembelajarannya, 2(1), 29-35. http://doi.org/10.25273/florea.v2i1.403

Surachman, dkk. (2014). Implementasi Scientific Process Pada Mata Pelajaran. Jurnal Pendidikan Matematika Dan Sains Tahun II, (2), 168-177. Retrieved from http://journal.uny.ac.id/index.php/jpms/article/do wnload/7168/6183

Suryaningsih, Y. (2017). Pembelajaran Berbasis Praktikum sebagai Sarana Siswa untuk Berlatih Menerapkan Keterampilan Proses Sains dalam Materi Biologi. Jurnal Bio Educatio, 2(2), 49-57.

Syafriyansyah, Eko Suyanto, \& I Dewa Putu Nyeneng. (2013). Pengaruh Keterampilan Proses Sains (KPS) terhadap hasil belajar fisika siswa melalui metode eksperimen dengan pendekatan inkuiri terbimbing. Jurnal Pembelajaran Fisika, 1(1). Retrieved from http://jurnal.fkip.unila.ac.id/index.php/JPF/article /view/209

Ulfa, S. W. (2016). Pembelajaran Berbasis Praktikum: Upaya Mengembangkan Sikap Ilmiah Siswa pada Pembelajaran Biologi. Nizhamiyah, VI(1), 65-75.

Ulva, V., Ibrohim, \& Sutopo. (2017). Mengembangkan Sikap Ilmiah Siswa SMP Melalui Pembelajaran Inkuiri Terbimbing pada Materi Ekosistem. Jurnal Pendidikan: Teori, Penelitian, Dan Pengembangan, 2(5), 622-626.

Zulyetti, D. (2017). Sikap Ilmiah dan Motivasi Belajar Mahasiswa dalam Praktikum Biologi Umum dengan Pendekatan Inkuiri Terbimbing di STKIP Abdi Pendidikan Payakumbuh. Saintifik@: Jurnal Pendidikan MIPA, 1(2), 70-75. 